\title{
Szylkret, bioorganiczny materiał w rzemiośle artystycznym - zagadnienia z zakresu materiałoznawstwa, technologii i stosowanych technik dekoracyjnych oraz niszczenie
}

zylkret był jednym z najwcześniej stosowanych do celów zdobniczych
materiałem. Trudność w pozyskiwaniu i wynikający z tego ograniczony dostęp, oryginalny walor estetyczny, na który składały się: barwa, deseń i przejrzystość, podatność na obróbkę wiążąca się jednak z dużą znajomościa jego właściwości, samej technologii i technik wykonywania z niego przedmiotów, zdecydowały o tym, że przez wiele stuleci należał on do tworzyw kosztownych i poszukiwanych przez rzemieślników, którzy sporządzali z niego wytwory wyrafinowane i zbytkowne.

Termin „szylkret” pochodzi od niemieckiego słowa Schildkröte, które oznacza żółwia. To właśnie z masy rogowej zewnętrznej warstwy pancerzy tych zwierząt otrzymywano ten materiał. Za wysoką jakość i ubarwienie najbardziej ceniono skorupy żółwi szylkretowych (Eretmochelys imbricata), stąd ich polska nazwa. Hainschwang i Leggio $^{1}$ podaja, że spośród sześciu gatunków morskich ${ }^{2}$, które posiadaja rogowy pancerz, stosunkowo rzadko prze-

1 T. Hainschwang, L. Leggio, The Characterization of Tortoise Shell and Its Imitations, "Gems \& Gemology", 2006, s. 38.

2 Są to: żółw zielony (ang. Green sea turtle, łac. Chelonia mydas), żółw szylkretowy (ang. Hawksbill sea turtle, łac. Eretmochelys imbricata), żółw zatokowy (ang. Kemp’s ridley sea tur- 
rabiano jeszcze tylko masę rogową pozyskiwaną z żółwi zielonych ${ }^{3}$ (Chelonia mydas). Według Remetter ${ }^{4}$ oraz DeMouthe ${ }^{5}$ dla skorup poławiano również żółwie karetta (Caretta Caretta). Przybliżenie, z którego gatunku otrzymano szylkret jest trudne i wymaga analizy chemicznej, np. określany jest stosunek dwóch aminokwasów: lizyny i histydyny ${ }^{6}$. W rzemiośle do różnych celów wykorzystywano również skorupy żółwi lądowych i słodkowodnych.

Rogowa część pancerza jest wytworem naskórka, powstającym w złożonym procesie biochemiczny nazywanym keratynizacja albo rogowaceniem. Wyspecjalizowane komórki nabłonkowe - keratynocyty - wytwarzaja białko - keratynę, która stopniowo wypełnia je. W końcowym etapie zanikają ich jądra i organelle cytoplazmatyczne, zahamowaniu ulega metabolizm. Powstaje powłoka utworzona ze ściśle upakowanych, martwych komórek - korneocytów ${ }^{7}$. Skorupę budują silnie zespolone ze sobą tarczki o teksturze warstwowej, będącej rezultatem okresowych przyrostów związanych ze wzrostem zwierzęcia. Nowa warstwa rogowa narasta pod tarczką i obejmuje większą powierzchnię naskórka, stąd młodsze przyrosty widoczne są na jej obrzeżach (Fot. 1). Tarcza grzbietowa (puklerz żółwi, karapaks) zbudowana jest z pięciu tarczek kręgowych ułożonych centralnie, przylegających do nich z dwóch stron czterech żebrowych, przy których ułożonych jest po jedenaście brzegowych rozdzielonych od strony głowy karkowa, a od ogona dwiema nadogonowymi. Plastron, tarczę brzuszna, buduja parzysto występujące tarczki szyjne, ramieniowe, piersiowe, brzuszne, udowe i odbytowe. Między przednimi a tylnymi kończynami obie części łączy spojenie

tle, łac. Lepidochelys kempii), żółw Karetta (ang. Loggerhead, łac. Caretta caretta), żółw oliwkowy (ang. Olive Ridley, łac. Lepidochelys olivacea), żółw natator (australijski) (ang. Flatback sea turtle, łac. Natator depressa).

3 Nazwa gatunku pochodzi od koloru tkanki tłuszczowej. Używana jest również inna - żółw jadalny. Jadalny, ponieważ jego mięso uważane jest za przysmak.

4 R. Remetter, Schildpatt, Das Material und Möglichkeiten seiner Verarbeitung, München 2002, s. 6 .

5 J. F. DeMouthe, Natural Materials. Sources, Propertis, and Uses, Amsterdam (2006), s. 142 .

6 T. Hainschwang, L. Leggio, op.cit., s.38.

A. Giroud, C. P. Leblond, The keratinization of epidermis and its derivates, especially the hair, as shown by X-Ray diffraction and histochemical studies, "Annals of the New York Academy of Sciences”, 53 (3), 2006, pp. 613-626, DOI: 10.1111/j.1749-6632.1951.tb31963.x. 
nazywane mostem. Kształt skorup determinuje gatunek żółwia, ale w obrębie niego zachodzą różnice ze względu na płeć. Pancerz oprócz ochrony żółwia przed czynnikami fizycznymi ma za zadanie maskować zwierzę. Mimetyzm przynosi w efekcie tak cenione ubarwienie oraz niepowtarzalny deseń wyrobów szylkretowych (Fot. 2).

Zasięg występowania żółwia szylkretowego jest szeroki. Zamieszkuje on rafy wszystkich oceanów. Wyróżniane są dwa jego podgatunki: występujący w Atlantyku Eretmochelys imbricata imbricata i Eretmochelys imbricata bissa żyjący w tropikalnych oraz subtropikalnych wodach Indopacyfiku. U żółwia szylkretowego tarczki karapaksu o charakterystycznym ubarwieniu - na żółtawym tle ciemnobrązowe smużenie - zachodzą jedna na drugą jak w zbroi karacenowej, a brzegowe są ząbkowane. Osiagaja grubość 9-12 $\mathrm{mm}^{8}$. Prawie płaski plastron jest jednolicie żółty. Pancerz tego żółwia może dochodzić do długości $1 \mathrm{~m}$. Większy, do $140 \mathrm{~cm}$, posiada, występujący w wodach od strefy równikowej po umiarkowaną, żółw zielony. Jego karapaks barwy oliwkowo-zielonej lub brunatnej w żółte plamki czy smugi jest spłaszczony i zwęża się w tylnej części, natomiast plastron może być jednolicie jasnożółty albo biały. Grubość tarczek wynosi zaledwie od 0,3 do 1,5 mm. Żółw karetta występuje w ciepłych wodach Atlantyku, Pacyfiku, Oceanu Indyjskiego, a także w Morzu Śródziemnym. Karapaks, długości $120 \mathrm{~cm}, \mathrm{w}$ różnych odcieniach brązu, ma nietypowo pięć par tarczek żebrowych. Ich grubość wynosi od 1 do $2 \mathrm{~mm}^{10}$. Plastron jest żółtawy ${ }^{11}$.

Właściwości szylkretu opisuje się zgodnie ze standardami przyjętymi dla kamieni ozdobnych. Jego gęstość wynosi od 1,29 do 1,35 g/ $\mathrm{cm}^{3}$. Twardość w skali Mohsa określana jest na poziomie 2,5, a więc materiał ten plasuje się między gipsem a kalcytem. Charakteryzuje się połyskiem od tłustego do woskowego i współczynnikiem załamania światła (IR $)^{12}$ na po-

8 T. Hainschwang, L. Leggio, op.cit., s. 38.

9 R. Remetter, op.cit., s. 8.

10 Ibid., s. 7.

11 Królestwo zwierzat pod red. D. Burnie, (Warszawa 2003), s. 368-369.

12 Refrakcja jest jedną z charakterystycznych cech kamieni służącą do ich wstępnej identyfikacji. 
ziomie 1,54. Wykazuje kredową jasnoniebieską fluorescencję z wyraźnym zaznaczeniem smug (Fot. 3) ${ }^{13}$.

Pod względem chemicznym podstawowym składnikiem budulcowym szylkretu jest białko z grupy keratyn ${ }^{14}$. Jego strukturę i wynikające z niej właściwości należy rozpatrywać biorąc pod uwagę kolejność - sekwencje - aminokwasów oraz przestrzenne ułożenie atomów w łańcuchu peptydowym $^{15}$. W ten sposób wyróżnić możemy cztery poziomy organizacji. Struktura pierwszorzędowa określa sekwencję aminokwasów, obejmuje położenie wszystkich wiązań kowalencyjnych, w tym wiązań disiarczkowych między resztami cysteiny. Struktura drugorzędowa opisuje konformacje ${ }^{16}$ łańcuchów polipeptydowych, rodzaj układu przestrzennego, który tworza: spiralę - helisę, harmonijkę lub inny regularny. Struktura trzeciorzędowa charakteryzuje trójwymiarową strukturę powstałą w wyniku wewnątrzcząsteczkowych oddziaływań pomiędzy łańcuchami bocznymi aminokwasów polipeptydów. Oddziaływania te sprawiają, że lokalne, liniowe domeny szkieletu polipeptydowego o konformacji helikalnej lub harmonijkowej zginaja się i fałduja tworząc jeszcze bardziej złożone struktury przestrzenne. Struktura czwartorzędowa opisuje wzajemne ułożenie łańcuchów polipeptydowych, ich asocjatów i aglomeratów w przestrzeni. Określa wzajemne położenie i oddziaływania poszczególnych polipeptydowych podjednostek składających się na kształt białka. Takimi oddziaływaniami moga być zarówno wiązania disiarczkowe, wiązania wodorowe, oddziaływania hydrofobowe i elektrostatyczne (jonowe) $)^{17}$.

13 N. Sobczak, T. Sobczak, Wielka encyklopedia kamieni szlachetnych i ozdobnych, Warszawa 1998, s. 371; T. Sobczak, N. Sobczak, Kamienie szlachetne pochodzenia organicznego, Warszawa 2013, s. 157.

14 L. Trusheim, Balancing ethics and restoration in the conservation treatment of an 18th century sewing box with tortoiseshell veneer, AIC Objects Specialty Group Postprints, 2011, 18, s. 127-147; T. Hainschwang, L. Leggio, op.cit., s. 36-52; R. Remetter, op.cit., s. 6-29.

15 R. K. Murray, D. K. Granner, P. A. Mayes, V. W. Rodwell, Biochemia Harpera, Warszawa 1995, s. 59-67; I. Żak, Chemia medyčna, Katowice 2001, s. 244-250.

16 Ukształtowanie przestrzenne cząsteczki mogące ulegać zmianom na skutek rotacji wokół pojedynczych wiązań chemicznych atomów lub grup atomów bez konieczności zrywania wiązań chemicznych.

17 R. K. Murray, D. K. Granner, P. A. Mayes, V. W. Rodwell, op.cit, s. 59-67 
Keratyny, pod względem biologicznym, to białka fibrylarne ${ }^{18}$, strukturalne zbudowane $\mathrm{z}$ monomerycznych jednostek aminokwasowych połączonych wiązaniami peptydowymi. W zależności od pochodzenia, występowania i/lub pełnionych funkcji w organizmie, białko to może się nieznacznie różnić zawartościa poszczególnych aminokwasów w łańcuchu peptydowym. Charakterystyczne dla makrocząsteczki keratyny jest występowanie w jej łańcuchu aminokwasu zwanego cysteiną ${ }^{19}$ (Rys. 1).

Aminokwas ten zawiera reaktywna grupę hydrosulfidowa - SH. To właśnie jej obecność determinuje ukształtowanie, strukturę białka. W wyniku reakcji utleniania cysteiny w makrołańcuchu peptydowym tworzą się liczne wiązania pomiędzy sąsiednimi łańcuchami, powstają w ten sposób mostki disiarczkowe (-S-S-), które stabilizują włóknistą strukturę keratyny, zwiększają odporność białka na działanie czynników fizycznych oraz chemicznych, np.: utratę rozpuszczalności w różnych cieczach, w tym w wodzie. Oprócz cysteiny białko to zbudowane jest także z aminokwasów kwasowych, tj. kwasu asparaginowego oraz kwasu glutaminowego, aminokwasów obojętnych, do których zliczana jest glicyna, alanina, fenyloalanina, leucyna, izoleucyna, walina i prolina, aminokwasów hydroksylowych w postaci tyrozyny, seryny i treoniny, jak również aminokwasów zasadowych - lizyny, argininy, histydyny i tryptofanu $^{20}$ (Rys. 1). Lańcuchy białek utworzone z powyższych aminokwasów moga albo zwijać się prawoskrętnie w helisę ( $\alpha$-konformacja) albo tworzyć strukturę plisowanych arkuszy, harmonijkową ( $\beta$-konformacja) (Rys. 2) ${ }^{21}$.

Przy czym $\alpha$-helisa powstaje spontanicznie, ponieważ jest konformacją najbardziej stabilną w przypadku łańcucha polipeptydowego, a jej

18 P. A. Coulombe, M. B. Omary, 'Hard' and 'soft' principles defining the structure, function and regulation of keratin intermediate filaments, "Current Opinion in Cell Biology", 2002, 14, s. 110-122; A. Rodziewicz, W. Laba, Keratyny i ich biodegradacja, „Biotechnologia”, 2006, 2 (73), s. $130-147$.

19 J. Skopińska-Wiśniewska, Keratyna w medycynie i inṡynierii tkankowej, „Polimery”, 2013, 58(2), s. $100-105$.

20 Loc.cit.

${ }^{21}$ J. Mckittrick, P.Y. Chen, S. G. Bodde, W. Yang, E. E. Novitskaya, M. A. Meyers, The structure, functions, and mechanical properties of keratin, "The Journal of The Minerals, Metals \& Materials Society”, 2012, 64 (4), s. 449-468, DOI: 10.1007/s11837-012-0302-8; A. Rodziewicz, W. Laba, op.cit., s. 130-147; R. K. Murray, D. K. Granner, P. A. Mayes, V. W. Rodwell, op.cit., s. 59-67. 
przekształcenie w $\beta$ jest możliwe tylko w wyniku dostarczenia do układu odpowiedniej ilości energii z zewnątrz na przykład w postaci ciepła. Struktury $\alpha$ na ogół spotykane są we włosach, rogach, pazurach oraz kopytach ssaków. Natomiast $\beta$-keratyny w piórach oraz dziobach ptaków, a także łuskach i pazurach gadów ${ }^{22}$. Naskórek żółwi utworzony jest z lekkich, elastycznych i miękkich $\alpha$-keratyn. Zapewnia on znakomitą elastyczność, tworzy barierę chroniąca przed utratą wody. Stanowi swego rodzaju rusztowanie, na którym znajduja się wytwory skórne w postaci łusek utworzonych z $\beta$-keratyn, które sa z kolei twarde, nieelastyczne. Mają one za zadanie zabezpieczać zwierzę przed urazami, czynnikami mechanicznymi ${ }^{23}$. W zależności od wyżej wymienionych właściwości, czy miejsca występowania poszczególnych struktur możliwa jest klasyfikacja keratyn na, tzw. keratyny „miękkie” oraz keratyny „twarde” ${ }^{24}$.

Specyficznym składnikiem szylkretu, który w dużej mierze decydował o walorach tego tworzywa, sa barwniki, w postaci feomelaniny z grupy me$\operatorname{lanin}^{25}$. To one zabarwiają masę rogowa, a ich koncentracja tworzy ten niepowtarzalny deseń (Fot. 2).

Żółwie skorupy używano do wyrobu ozdób już od starożytności, a wytwarzany $\mathrm{z}$ nich szylkret był jednym z drogocennych materiałów

22 J. Mckittrick, P.Y. Chen, S. G. Bodde, W. Yang, E. E. Novitskaya, M. A. Meyers, op.cit., s. 449-46; J. Skopińska - Wiśniewska, op.cit, s. 100-105.

23 J. E. Moustakas-Verho, G. O. Cherepanov, The integumental appendages of the turtle shell: an evo-devo perspective, "Journal of Experimental Zoology Part B: Molecular and Developmental Evolution”, 324 B, 2015, pp. 221-229, Doi: 10.1002/jez.b.22619; H. H Bragulla, D. G Homberger, Structure and functions of keratin proteins in simple, stratified, keratinized and cornified epithelia, "Journal of Anatomy", 214(4), 2009, pp. 516-559, DOI: 10.1111/j.14697580.2009.01066.x; L. Alibardi, E. Spisni, M. Toni, Differentation of the epidermis in turtle: an immunocytochemical, autoradiographic and electrophoretic analysis, "Acta Histochemica", 106 (5), 2004, pp. 379-395, DOI: 10.1016/j/acthis.2004.06.002; L. D. Valle, A. Nordi, C. Gelmi, M. Toni, D. Emmera, L. Alibardi, Beta - Keratins of the crocodilian epiderms: composition, structure and phylogenetic relationship, "Journal of Experimental Zoology Part B: Molecular and Developmental Evolution”, 312 B, 2009, pp. 42-57, Doi: 10.1002/jez.b.21241.

${ }^{24}$ J. Mckittrick, P.Y. Chen, S. G. Bodde, W. Yang, E. E. Novitskaya, M. A. Meyers, op.cit., s. 449-46; A. Rodziewicz, W. Laba, op.cit., s. 130-147; J. Skopińska-Wiśniewska, op.cit, s. 100-105.

25 A. Roulin, A. Mafli, K. Wakamatsu, Reptiles Produce Pheomelanin: Evidence in the Eastern Hermann's Tortoise (Eurotestudo boettgeri), "Journal of Herpetology", 2013, 47(2), s. 258-261. 
Dalekiego Wschodu, który trafil do Egiptu. Przedmioty wykonane z niego znaleziono w nubijskich grobach. Przez starożytnych Greków i Rzymian wykorzystywany był głównie do wyrabiania biżuterii - pierścionków, naszyjników - oraz akcesoriów toaletowych - szczotek, grzebieni, a także instrumentów jak chelys. Rzymianie stosowali go także jako okładzinę meblową. Od końca XVI wieku w wielu częściach Europy skorupy żółwi przetwarzano na luksusowe przedmioty. Szylkret ceniony był w kręgach wielu kultur. W Chinach nie tylko raczono się mięsem żółwi zielonych, ale również wykorzystywano ich cienkie, transparentne skorupy do wyrobu lamp. W Japonii wytwarzanie przedmiotów z szylkretu rozkwitło w okresie Endo. Materiał był importowany, dlatego miasto portowe Nagasaki stało się centrum ich powstawania. Wykonywano z niego ozdoby do włosów, oprawki okularów. Wykorzystywano naturalną właściwość tego materiału, który pod wpływem ludzkiego ciepła dopasowywał się do kształtu głowy. Odkrycia nowych kontynentów i łowisk żółwia, rozszerzenie światowego handlu i płynące z tego zyski przyczyniły się do nastania „szylkretowej mody”. Zaczęto go popularnie używać do produkcji szerokiej gamy asortymentu, jak grzebienie, tabakierki, oprawki do okularów, a nawet kostki do gitary.

Technologia przetwarzania masy rogowej opierała się na jej specyficznej właściwości. Podgrzana staje się na tyle plastyczna, że można ją kształtować, a powoli schładzana, twardnieje zachowując nadana formę. Materiał mięknie, ponieważ ciepło powoduje destrukcję wiązań wodorowych, oddziaływań elektrostatycznych oraz hydrofobowych. Struktura białka przekształca się z pofałdowanej w ,rozprostowana”. W trakcie studzenia powraca do najkorzystniejszej energetycznie formy, a wyżej wymienione wiązania i oddziaływania pomiędzy atomami i/lub ugrupowaniami zostają odtworzone, nadając tworzywu sztywność w narzuconym kształcie. Według Trusheim ${ }^{26}$ materiał mięknie, ponieważ ciepło rozbija niektóre wiązania disiarczkowe. Daje to błędne wyobrażenie o tym procesie oraz nie przedstawia jego istoty, bo chociaż może dojść do rozerwania niewielkiej ich części, nie wpłynie to zasadniczo na uplastycznienie tworzywa. Destrukcja wielu zaś doprowadzi do rozpadu przestrzennej struktury keratyny, co należy rozumieć jako jego zniszczenie.

26 L. Trusheim, op.cit., s. 130. 
Przygotowanie szylkretu zaczynało się od mechanicznego usunięcia z pancerza narośli i wyrównania jego powierzchni. Następnie uplastyczniano go w kąpieli we wrzącej wodzie $z$ dodatkiem soli, jak i również oleju ${ }^{27}$. W ten sposób regulowano optymalną temperaturę procesu. Przekroczenie $110^{\circ} \mathrm{C}$ skutkowało ciemnieniem materiału, a o kolejne 40 stopni jego zniszczeniem $^{28}$. Następnie, aby uzyskać płaty szylkretu, fragmenty skorup prasowano pod naciskiem nagrzanych worków z piaskiem lub metalowych płyt. W ten sposób osiagano wymagane powolne stygnięcie. Z czasem stosowano bardziej zaawansowaną metodę. Wprowadzono prasy, a niekiedy skorupy prostowano wprost w kapieli. Tak przygotowane płaty wyrównywało się szlifując do uzyskania jednakowej grubości. Duże, czy grubsze arkusze otrzymywano poprzez zgrzewanie, cieńsze - rozdzielając. Wyroby przestrzenne kształtowano w nagrzanych formach metalowych. Gotowe wyroby szlifowano i polerowano delikatnymi materiałami ściernymi. Na końcowy połysk wpływało dodawanie do past polerskich olejów nieschnących: oliwy $^{29}$ czy oleju migdałowego ${ }^{30}$.

Obróbka masy rogowej powoduje znaczące zmiany zarówno w teksturze, jak i na jej powierzchni (Fot. 6-9). Widoczne w obrazowaniu SEM charakterystyczne, o ostro zakończonych krawędziach, tarczki przyrostowe skorupy ulegaja zanikowi. Zostaja ,sprasowane” pod wpływem działającej siły nacisku oraz podwyższonej temperatury. Tekstura jest bardziej zwarta w porównaniu do materiału niepoddanego obróbce. Jednocześnie w obrębie pojedynczych tarczek dochodzi do ich zniszczenia, drobne fragmenty ulegaja eksfoliacji (Fot. 8). Może to być spowodowane utratą wody (dodatek oleju do kapieli czy do past polerskich miał częściowo zapobiegać temu procesowi), a w konsekwencji skurczowi materiału. Złuszczanie może wynikać również z mikrouszkodzeń powstałych w trakcie obróbki płatów szylkretu. Na jego powierzchni (Fot. 6), obserwowane są także nieliczne fragmenty, które wystaja pod niewielkim kątem w stosunku do płaszczyzny powierzchni analizowanego materiału. Takie rozwinięcie powierzchni wła-

27 R. Remetter, op.cit., s. 19.

28 Loc.cit.

29 Antyki. Kompedium wiedsy dla kolekcjonerón i mitośnikón staroci, (Warszawa 1995), s. 252.

30 Loc.cit. 
ściwej prowadzi do zmniejszenia transparentności. Jest to jeden z powodów matowienia powierzchni szylkretu wraz z upływem czasu.

Tak przygotowany materiał poddawano dalszym zabiegom. Powierzchnie przedmiotów wykonanych z szylkretu pokrywano reliefem wycinanym w jego masie, bądź wytłaczanym na ciepło. Bogatym źródłem innowacji i kreacji stała się sztuka łączenia z szylkretem innych materiałów. Wyroby kameryzowano (Fot. 10). Encyclopédie, ou dictionnaire raisonné des sciences, des arts et des métiers wymienia kilka technik osadzania w masie rogowej elementów wykonanych ze stopów złota, srebra, a także mosiądzu. Pierwszą z nich jest incruste, czyli tworzenie kunsztownych ornamentów przez wprasowywanie na ciepło w masę rogową cienkich blaszek o różnych kształtach (Fot. 11). Kolejną wymienioną techniką dekoracyjna jest piqué. Nazwa nie ma polskiego odpowiednika; słowo tłumaczone może być jako pikowanie, czy szpilkowanie. Misterne wzory zestawiano ze szpilek, które na ciepło prostopadle wbijano w szylkret tak, aby ich podstawy tworzyły z nim powierzchnię. Po ostygnięciu oba materiały trwale łączyły się. Popularnie stosowano szpilki o kształcie walca; we Francji używano również o przekroju poprzecznym gwiazdki, a w Anglii rurki. Prace wykonane złotem nazywano piqué d'or, a srebrem piqué d'argent. Sztyftami zdobiono regularnie cała powierzchnię, układano z nich światłocieniowe przedstawienia lub dopełniano nimi dekorację wykonaną inkrustacja. Do upowszechnienia techniki przyczyniły się prace Laurentiego z Neapolu. Swój najwyższy rozkwit osiagnęła w XVII i XVIII wieku we Francji. W 1770 roku Anglik Matthew Boulton zmechanizował proces osadzania sztyftów. Technika o nazwie coulé polegała na wprowadzaniu płaskowników i tworzeniu z nich misternej sieci, natomiast brodé, czyli haftowanie, łączyła wszystkie opisywane metody. Sięgano po sceny chinoiserie, wzory geometryczne i arabeski.

Kolejnym przejawem innowacyjności w łączeniu materiałów jest markieteria (markietaż), technika zdobnicza stosowana w meblarstwie i przy wytwarzaniu drobnych przedmiotów. Z fornirów, płatów kości słoniowej, macicy perłowej, szylkretu, folii metali oraz innych drogocennych materiałów na powierzchni zdobionego wyrobu układane sa wzory o bogatej ornamentyce. Jednym z największych twórców stosujących tę technikę był Charles André Boulle. Artysta, który trafil na odpowiedni czas, okres panowania Ludwika XIV, porę nieokiełznanej okazałości i wystawności, który z 
niezwykłą umiejętnością i wyczuciem łączył ze sobą te różne materiały tworząc dzieła monumentalne, a zarazem harmonijne. Najbardziej znany jest z prac opartych na połączeniu szylkretu i mosiądzu. Stosowana przez niego technika stała się źródłem inspiracji i naśladownictwa. Zdobione w ten sposób przedmioty popularnie określa się terminem styl Boulle’a (Fot. 12, 13). W inkrustacjach i markieteriach szylkret przyklejany był do podłoża. Czasami pod przejrzysty materiał jako tło układano papier lub pokrywano odwrocie klejem rybim z dodatkiem pigmentów o kolorze czarnym, zielonym, czerwonym lub białym, co miało również przysłonić defekty materiału ${ }^{31}$.

W szylkrecie obserwuje się wysoki stopień uporządkowania strukturalnego (Rys. 2.), który zapewniają liczne wiązania wodorowe, elektrostatyczne, hydrofobowe i disiarczkowe. Wraz z jego wzrostem, w materiałach wielkocząsteczkowych, obserwuje się zmiany dotyczące zarówno cech optycznych, jak i mechanicznych. Rośnie ich twardość, kruchość oraz ścieralność, a obniżeniu ulega rozszerzalność cieplna, transparentność oraz chłonność wody $^{32}$, dlatego szylkret jest kruchym, łupliwym tworzywem o niskiej odporności na zarysowanie, a wyroby z niego podatne są na zniszczenia mechaniczne (Fot. 14). Ich powierzchnia łatwo traci poler (Fot. 15). Sam proces technologiczny pozyskiwania szylkretu wpływał negatywnie na właściwości finalnego produktu. Naprężenia wewnętrzne, które powstaja podczas formowania przyczyniaja się do późniejszego rozwarstwienia materiału czy nawet peckania (Fot. 16, 17), a przy współudziale wilgoci moga doprowadzić do odkształceń (Fot. 14). Powstające mikroskopijne przestrzenie między warstwami szylkretu powodują zmniejszenie przepuszczalności światła (Fot. 15).

Białka, w tym keratyna, wykazuja różną wrażliwość na działanie czynników chemicznych i fizycznych. Jej degradację zaobserwowano w efekcie działania podwyższonej temperatury, roztworów kwasów i zasad oraz enzymów. Pod ich wpływem, w różnym stopniu, zniszczeniu ulegaja struktury drugorzędowe, trzeciorzędowe lub czwartorzędowe ${ }^{33}$. Takie zmiany destrukcyjne w świecie białek nazywane są denaturacja.

31 L. Trusheim, op.cit., s. 130.

32 J. Ciabach, Wtaściwości symic sztucznych stosowanych w konserwacji zabytków, Torun 2001, s. 28-34; D. Żuchowska, Polimery konstrukcyjne, Warszawa 2000, s. 49-53.

33 R. K. Murray, D. K. Granner, P. A. Mayes, V. W. Rodwell, op.cit., s. 59-67. 
Pod wpływem podwyższonej temperatury keratyna ulega rozkładowi. W zależności od jej wysokości następuje skrócenie łańcuchów polipeptydowych, rozpad na oligomery bądź aminokwasy. Ogrzanie do $130-140^{\circ} \mathrm{C}$ prowadzi do przemian jej struktury. W temperaturze około $180-190^{\circ} \mathrm{C}$ widoczne sa już zmiany we włóknistej strukturze keratyn, zaś dalsze jej ogrzewanie, powyżej $200^{\circ} \mathrm{C}$, powoduje finalny rozkład aminokwasów ${ }^{34}$.

W wyniku zmiany $\mathrm{pH}$ środowiska (oddziaływania z kwasami mineralnymi lub zasadami) we włóknach białkowych następuje rozrywanie wiązań peptydowych. Stopień degradacji uzależniony jest od rodzaju, stężenia kwasu bądź zasady, pH środowiska oraz od czasu wpływu takiego środowiska na łańcuch polipeptydowy. W wyniku alkalizacji środowiska keratyn ulega spęcznieniu. Rozerwaniu wiązań peptydowych i disiarczkowych towarzyszy wzrost rozpuszczalności keratyn w roztworach zasad. W wyniku degradacji dochodzi do zmniejszenia masy cząsteczkowej, wzrostu plastyczności materiału i pogorszenia jego wytrzymałości mechanicznej. Zdenaturowane białka cechują się wzrostem asymetrii cząsteczek, kąta skręcenia płaszczyzny światła spolaryzowanego oraz podatności na hydrolizę enzymatyczną ${ }^{35}$.

Działanie mikroorganizmów na keratynę prowadzi do biodegradacji spowodowanej przede wszystkim hydrolizą enzymatyczną. Działanie niszczące wykazują substancje wytwarzane przez bakterie z rodziny Bacillus, Streptomyces lub grzyby, takie jak Paecilomyces marquandi $\imath^{36}$.

Szylkret należał do bardzo kosztownych tworzyw, dlatego na rynku pojawiły się materiały szylkretopodobne. Odtwarzano jego kolor i wzór zabarwiając róg oraz kość. W XIX wieku do imitacji zaczęto używać tworzyw sztucznych. Jednym z pierwszych był azotan celulozy - celuloid zsyntetyzowany w 1862 roku przez Aleksandra Parksa ${ }^{37}$. Problem z użyciem tego tworzywa związany był z jego bardzo duża palnościa. Jeżeli w efekcie działania kwasem azotowym(V) na celulozę, produkt zawierał resztki kwasów, to mógł on ulec samozapłonowi; zapalał się pod wpływem iskry, a na-

34 M. Prochoń, G. Janowska, A. Przepiórkowska, A. Kucharska-Jastrząbek, Stabilność termiczna i palność biorozkładalnych materiatón elastomeronych, „Polimery”, 2013, 58, (5), s. 413-420.

35 I. Żak, op.cit., s. 250-252.

36 J. Skopińska-Wiśniewska, op.cit., s. 100-105; A. Rodziewicz, W. Łaba, op.cit., s. 130-147.

37 T. Hainschwang, L. Leggio, op.cit., s. 36-52. 
wet ciepła. Celuloid cechował się małą stabilnością na światło słoneczne. W krótkim czasie wykazywał znaczny stopień zżółknięcia ${ }^{38}$. W 1892 roku otrzymano octan celulozy, który pozbawiony był wad swojego poprzednika. Niestety ulegał hydrolizie. Z odszczepianiem się niektórych grup acylowych z makrocząsteczki zachodziło jednoczesne skracanie się łańcuchów, a produkt uboczny tego procesu - kwas octowy - zakwaszał środowisko przyczyniając się do dalszej jego destrukcji. Kolejną wadą octanu celulozy jest higroskopijność, absorbuje więcej wody od nitrocelulozy ${ }^{39}$. Kolejnym tworzywem, który służył do imitacji szylkretu, był galalit ${ }^{40}$, popularnie nazywany mlecznym kamieniem, sztucznym rogiem, czy kazeinitem, otrzymany w 1897 roku w efekcie współpracy Wilhelma Krischa i Adolfa Spittelera na drodze reakcji kazeiny z formaldehydem. Oczywista zaleta tego materiału, na ówczesne czasy, była jego stabilność; nie należał do materiałów łatwopalnych, wykazywał obojętność na działanie wielu rozpuszczalników organicznych. Tworzywo jest trudne w obróbce ze względu na swoją twardość. Głównym źródłem zmian galalitu jest wilgoć, która może prowadzić do trwałego rozkładu z mikroskopijnymi, charakterystycznymi pęknięciami obserwowanymi w tworzywie. Pod wpływem jej działania forma ulegała deformacji ${ }^{41}$. W 1907 roku Leo Baekeland opatentował swoje tworzywo pod nazwą bakelitu. Jest to tworzywo sztuczne otrzymywane w wyniku kondensacji fenolu i formaldehydu ${ }^{42}$, które łatwo się formowało i cechowało się dobrą odpornością na działanie czynników środowiskowych. Współcześnie do imitacji szylkretu wykorzystuje się inne popularne duroplasty, takie jak żywice epoksydowe czy żywice poliestrowe.

Imitacje szylkretu otrzymywane z tworzyw sztucznych sa jednak bardzo łatwe do odróżnienia od oryginału, chociażby przy użyciu prostej techniki

38 J. Ciabach, Żywice $i$ tworyywa sætuczne stosowane w konserwacji zabytków, Torun 1998, s. $198-200$.

39 Loc.cit.

40 T. Hainschwang, L. Leggio, op.cit., s. 36-52.

41 C. Paris, S. Lecomte, C. Coupry, ATR-FTIR spectroscopy as a way to identify natural protein-based materials, tortoiseshell and horn, from their protein-based imitation, galalith, "Spectrochemica Acta" Part A, 2005, 62, s. 532-538

42 T. Hainschwang, L. Leggio, op.cit., s. 36-52. 
instrumentalnej, jaką jest FTIR ${ }^{43}$. Na widmie szylkretu (Rys. 3) widoczne sa charakterystyczne pasma absorpcyjne przypisane odpowiednim ugrupowaniom. Sygnał o dużej intensywności z maksimum przy około $3300 \mathrm{~cm}^{-1}$ przypisany jest drganiom grup OH oraz NH. Pasma, przy około 2950, 2850, $1450 \mathrm{~cm}^{-1}$, odpowiadaja drganiom wiązań węgiel - wodór.

Sygnały z maksimum przy około 1650, 1530 oraz $1240 \mathrm{~cm}^{-1}$ nazywane sa potocznie pasmami amidowymi (odpowiednio pierwsze, drugie i trzecie pasmo amidowe) i są charakterystyczne dla peptydów i białek. Jednak najbardziej przydatne informacje $z$ widma FTIR zbierane sa w zakresie 900$-500 \mathrm{~cm}^{-1}$. Widmo w tym zakresie jest złożone, lecz można wyróżnić cztery sygnały z maksimum absorpcji przy około 830, 745, 675 oraz $550 \mathrm{~cm}^{-1}$. Charakterystyczna absorpcja promieniowania w tym rejonie stanowi swoiste „linie papilarne” (Rys. 3), dzięki którym możliwa jest identyfikacja keratyn ${ }^{44}$. Brak na widmie opisywanych pasm amidowych oraz przede wszystkim ,linii papilarnych" jest podstawą do odróżnienia imitacji szylkretu od jego oryginału (Rys. 4).

Niewątpliwie szylkret jest bardzo ciekawym pod względem materiałoznawczym tworzywem o bogatej tradycji stosowania w rzemiośle artystycznym, które pobudziło twórców do opracowania wyrafinowanych technik zdobniczych. Niestety cieniem na tych osiagnięciach ludzkich kładzie się przetrzebienie populacji żółwi morskich, odławianych dla znacznego zysku i wyłaczenie dla pozyskania masy rogowej z ich pancerzy. Okrutne metody oddzierania skorup z żywych zwierząt sa również etycznie nie do przyjęcia. Duży popyt na szylkret przyczynił się do tak drastycznego spadku ich populacji, że zagroziło im wyginięcie. Ostatecznie, w 1973 roku, handel szylkretem został zakazany przez konwencję o międzynarodowym handlu zagrożonymi wyginięciem gatunkami dzikich zwierząt i roślin (CITES). Zastosowanie tworzyw sztucznych do imitacji szylkretu częściowo rozwiązywało powyższy problem. Dawały się łatwo barwić w masie, formować, aby uzyskiwać różne kształty, jednak zarówno swoimi właściwościami fizykochemicznymi, jak i mechanicznymi znacznie różnią się od oryginału.

43 Ibid., s. 36-52.

44 Ibid., s. 36-52. 


\section{Summary}

\section{Tortoiseshell, Bioorganic Material in Artistic Crafts \\ - Issues of Material Science, Technology and Design Techniques, and Destruction}

Tortoiseshell was one of the earliest materials which has been used to the ornamental purposes. It is obtained from the outer layer of dermal bone of three species of sea turtles: tortoiseshell, green and loggerhead. Dermal bone is formed by scutes, strongly interconnected with each other, with characteristic layered structure. Chemically has a similar composition to the horn and mainly consists of keratin - hydrophilic, fibrous protein, insoluble in water with good resistance to physical and chemical agents. Dermal bone has a two-phase structure, in which keratin fibers are embedded in the amorphous matrix with a high content of sulfur. Tortoiseshell properties shall be described with accordance by the standards adopted for decorative stone. Carapace was used for making ornaments since antiquity in many cultures. In 1973 introduced global ban on trade of tortoiseshell on the basis of the Convention on International Trade in Endangered Species. Processing of dermal bone based on its forming at high temperature, of around $100^{\circ} \mathrm{C}$ and cooling to room temperature with a given form. Surfaces of objects made from tortoiseshell were carved, inlay decorated and piqué technique. It was also used in marquetry. The finished product is susceptible to mechanical damage, loses its shine, it darkens, delaminate, and may be biodegradable. 


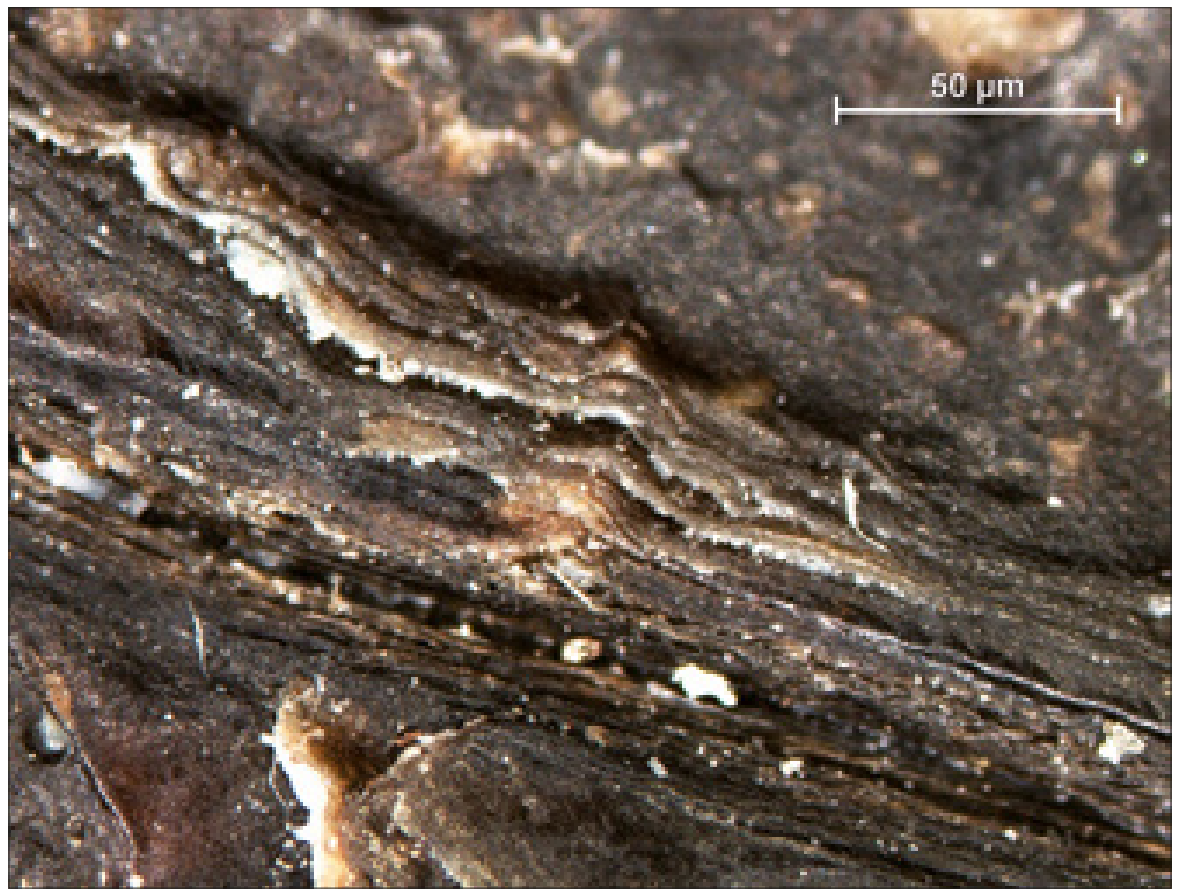

Fot. 1. Przyrosty na obrzeżach przylegających tarczek na przykładzie skorupy żółwia błotnego (Emys orbicularis); eksponat Muzeum Przyrodniczego Wydziału Biologii (Fot. Alina Tomaszewska-Szewczyk)
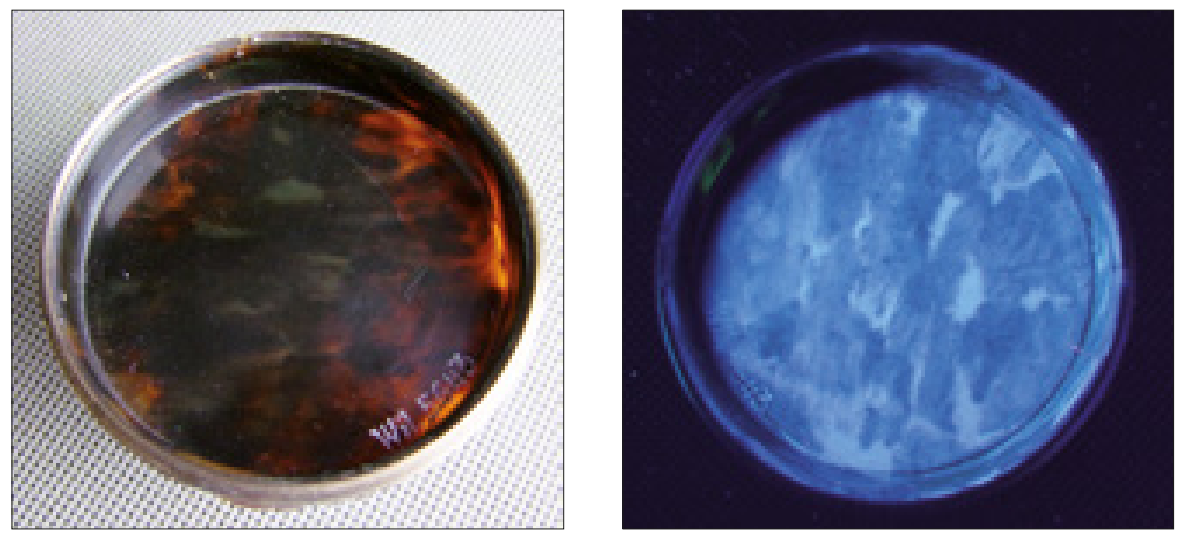

Fot. 2-3 Szylkret w świetle widzialnym i w świetle UV (Fot. Alina Tomaszewska-Szewczyk) 

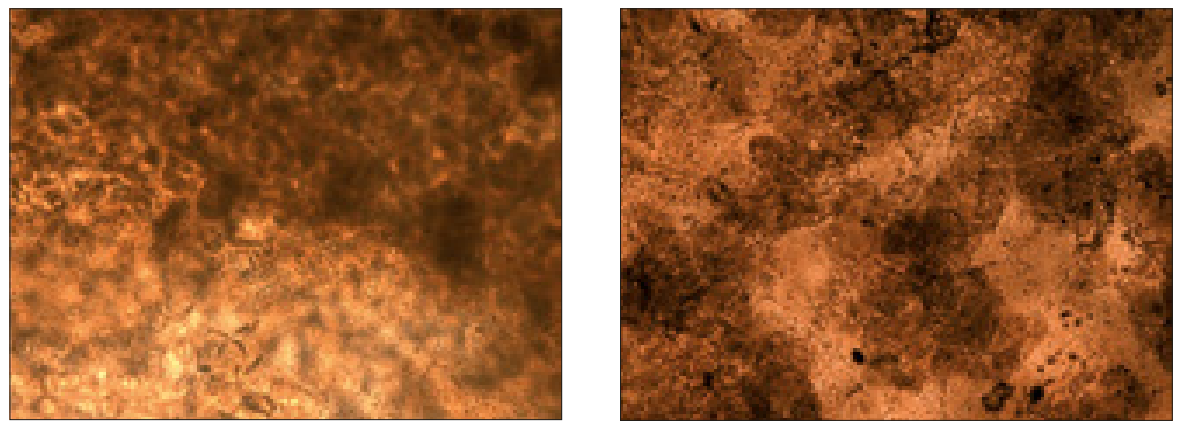

Fot. 4-5. Warstwa rogowa żółwia żółtolicego (Trachemys scripta troostii) oraz szylkret (z prawej strony); obrazowanie w świetle widzialnym przechodzącym, powiększenie 40x (Fot. Janusz Niedojadło)
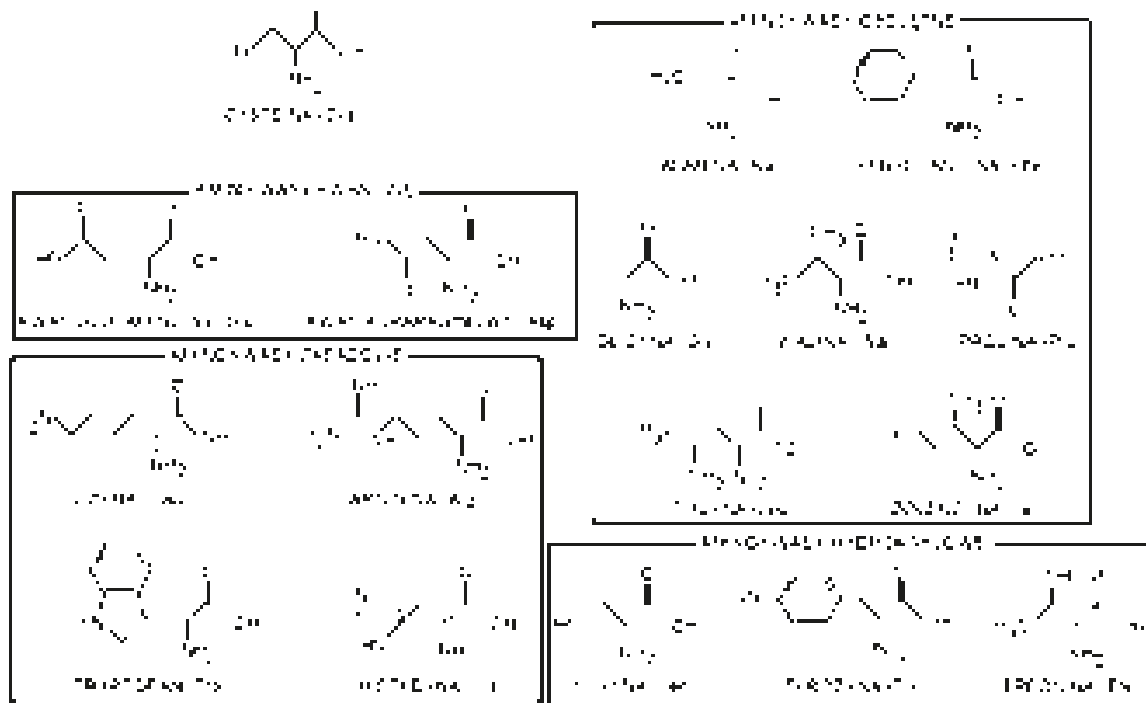

Rys. 1. Budowa chemiczna aminokwasów tworzących strukturę keratyn (Rys. Andrzej Podgórski)

* Opracowanie na podstawie R. K. Murray, D. K. Granner, P. A. Mayes, V. W. Rodwell, op.cit., s. 35-44. 

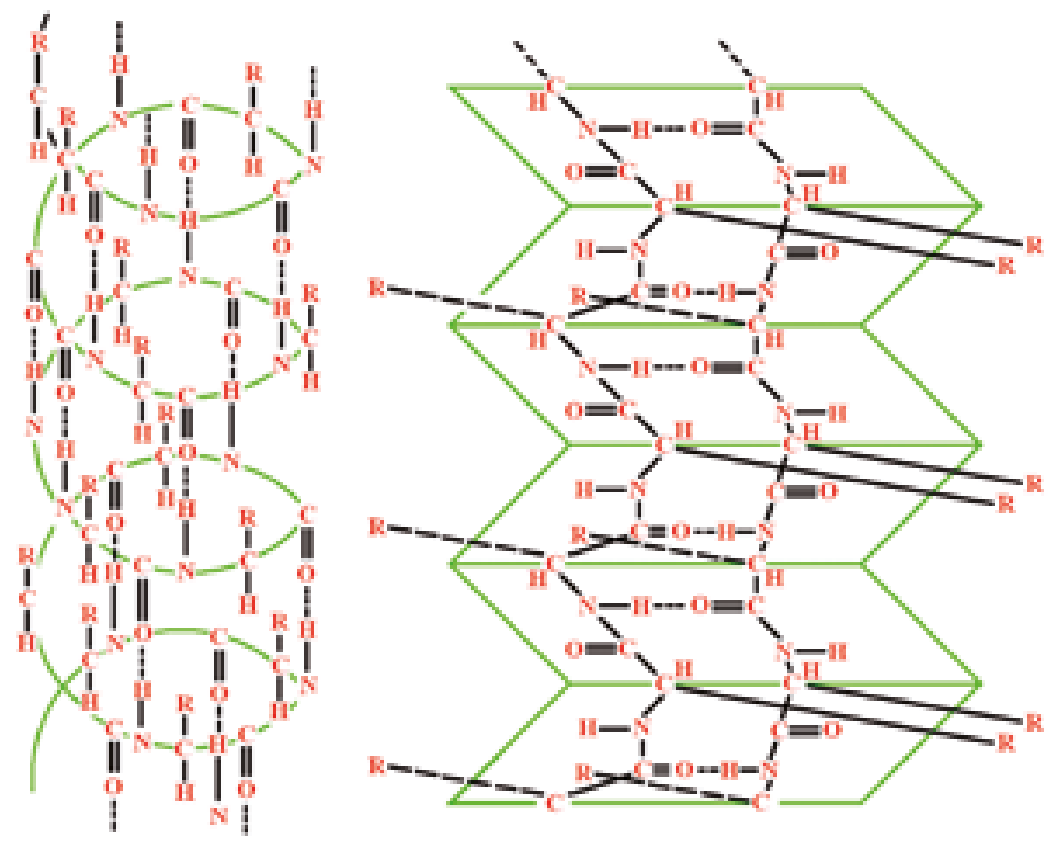

Rys. 2. Możliwe struktury przestrzenne keratyn, po lewej konformacja $\alpha$-helisa, po prawej konformacja $\beta$-harmonijka (Rys. Andrzej Podgórski)*

* Opracowanie na podstawie R. K. Murray, D. K. Granner, P. A. Mayes, V. W. Rodwell, op.cit., s. 59-67. 

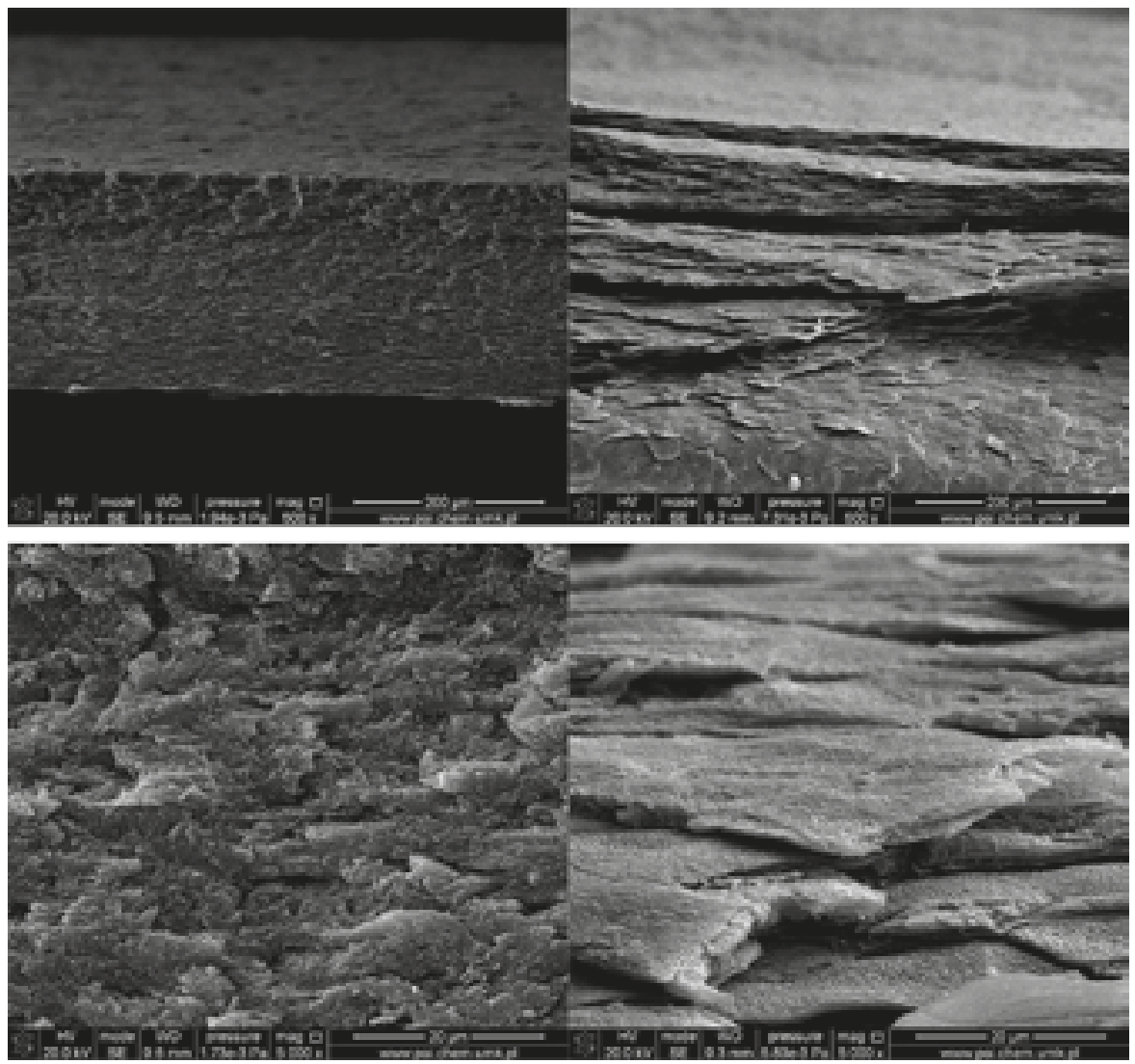

Fot. 6-9. Obrazowanie SEM* przełamu szylkretu (z lewej strony) oraz warstwy rogowej żółwia żółtolicego (Trachemys scripta troostii) (Pracownia Analiz Instrumentalnych, Wydział Chemii, UMK)

* Zastosowano skaningowy mikroskop elektronowy 1430 VP LEO Electron Microscopy Ltd z detektorem elektronów wtórnych SE oraz zmienną próżnię. Próbki zostały przed analizą napylone plazmowo warstwą stopu AuPd w atmosferze argonu napylarką Quorum Technologies. 


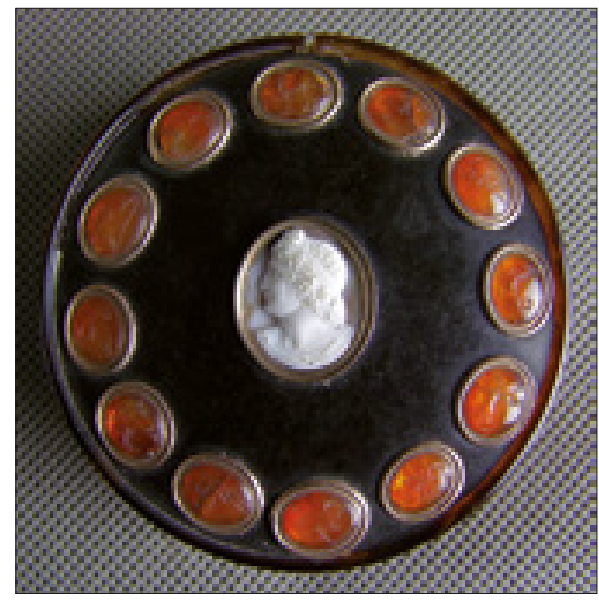

Fot. 10. Pudełeczko szylkretowe dekorowane kameryzacją (fot. A. Tomaszewska-Szewczyk)

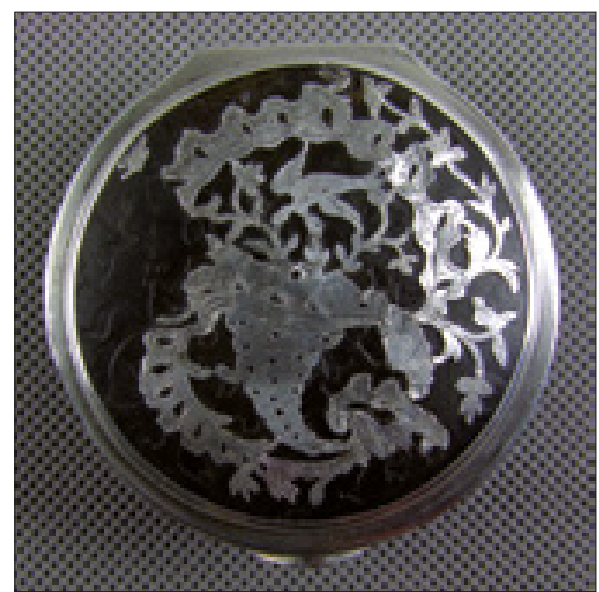

Fot. 11. Pudełeczko wykonane z szylkretu inkrustowane wycinanymi i grawerowanymi ornamentami z blachy srebrnej (Fot. A. Tomaszewska-Szewczyk) 

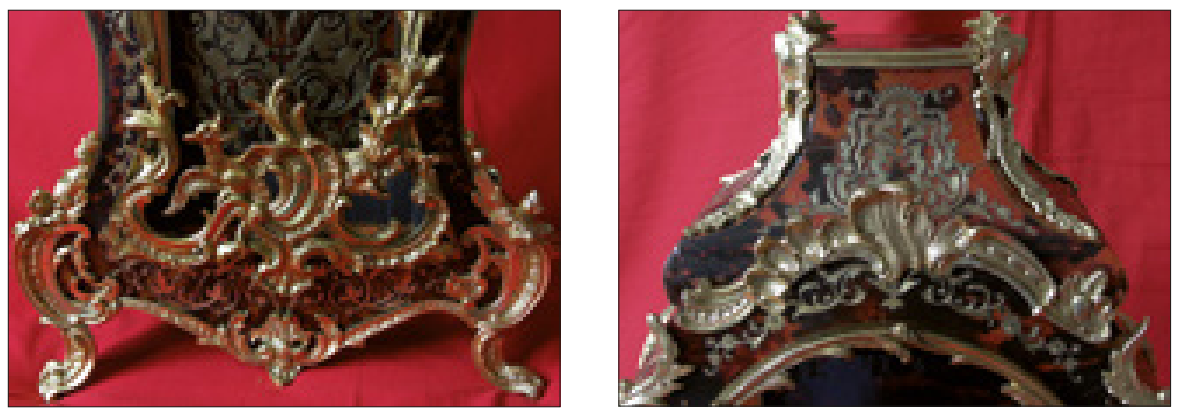

Fot.12-13. Obudowa zegara w stylu Boulle’a, okładzina szylkretowa wycinana w ażurowe wzory wypełnione grawerowanymi aplikacjami wykonanymi z cienkiej blachy mosiężnej oraz złocone elementy odlane z mosiądzu (fot. R. Szewczyk)
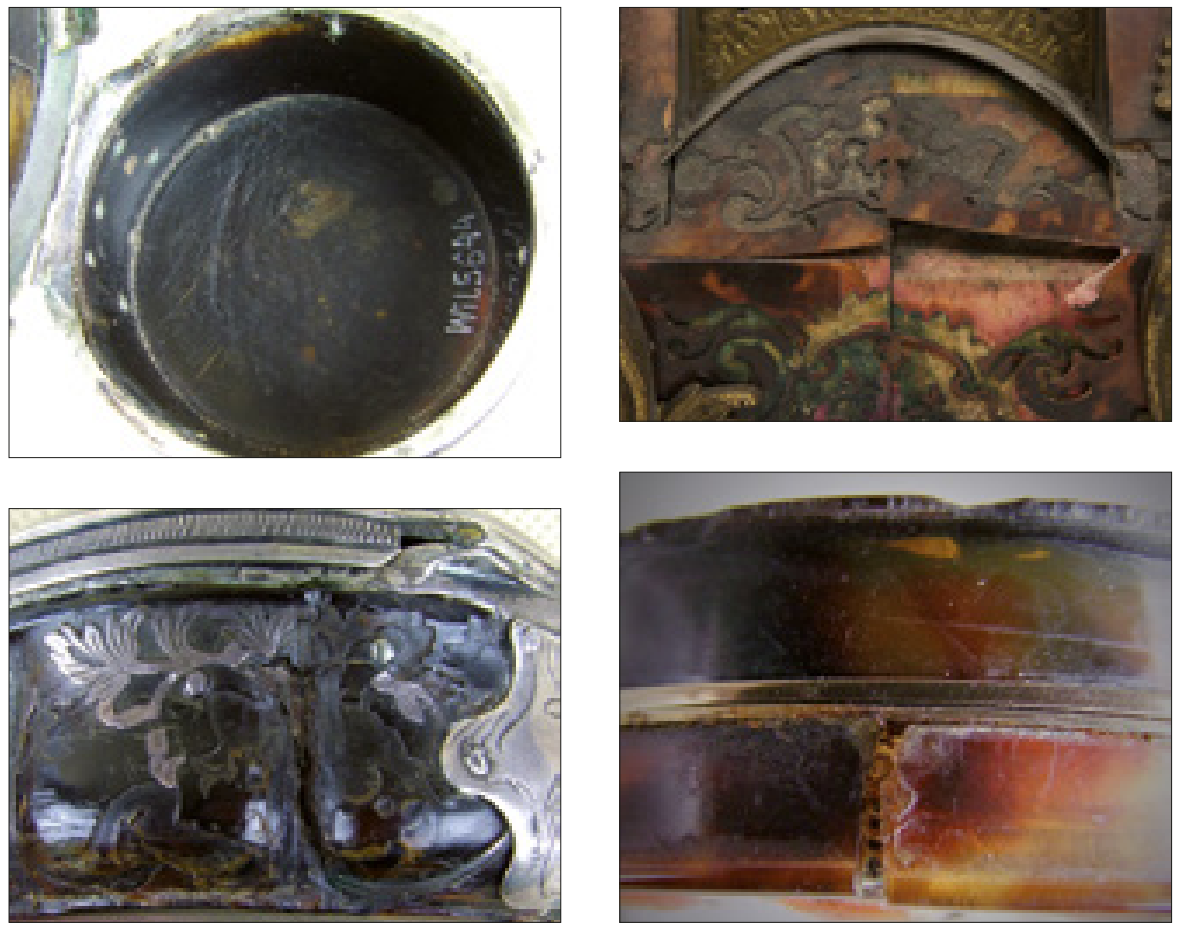

Fot. 14-17 Przykłady zniszczeń wyrobów szylkretowych; zarysowania, utrata poleru, deformacje, pękanie i rozwarstwienie (Fot. A. Tomaszewska-Szewczyk) 


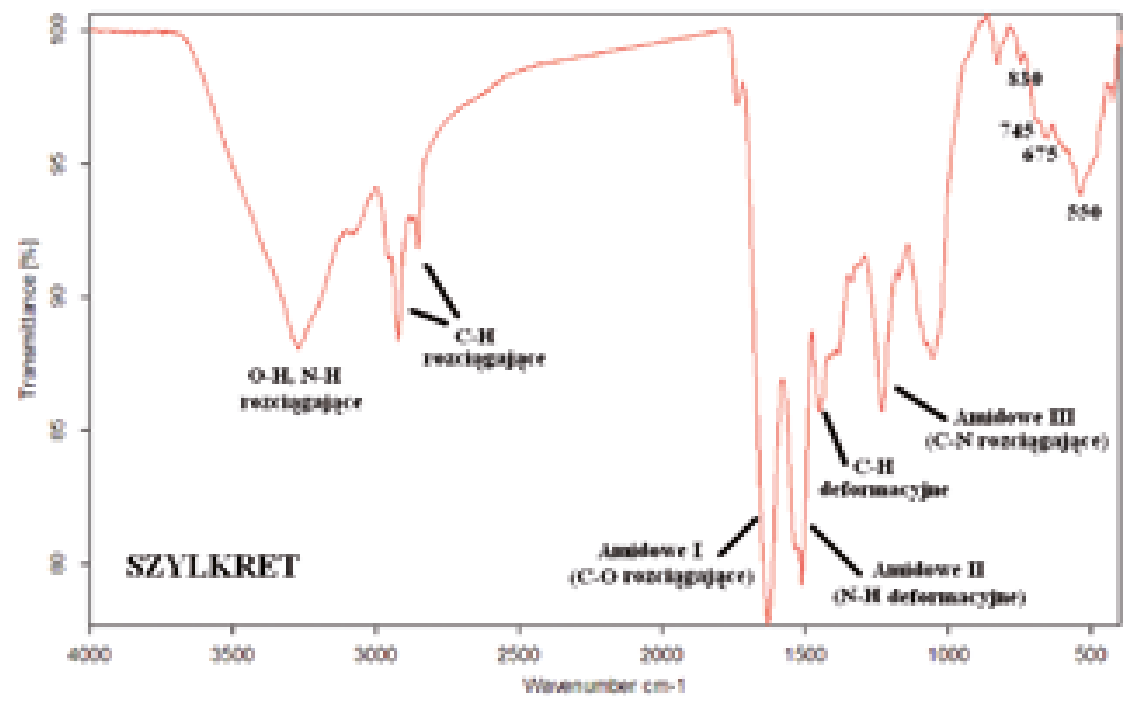

Rys. 3. Widmo w podczerwieni szylkretu oraz przypisane charakterystyczne pasma (Zakład Konserwacji Elementów i Detali Architektonicznych, Wydział Sztuk Pięknych, UMK) 


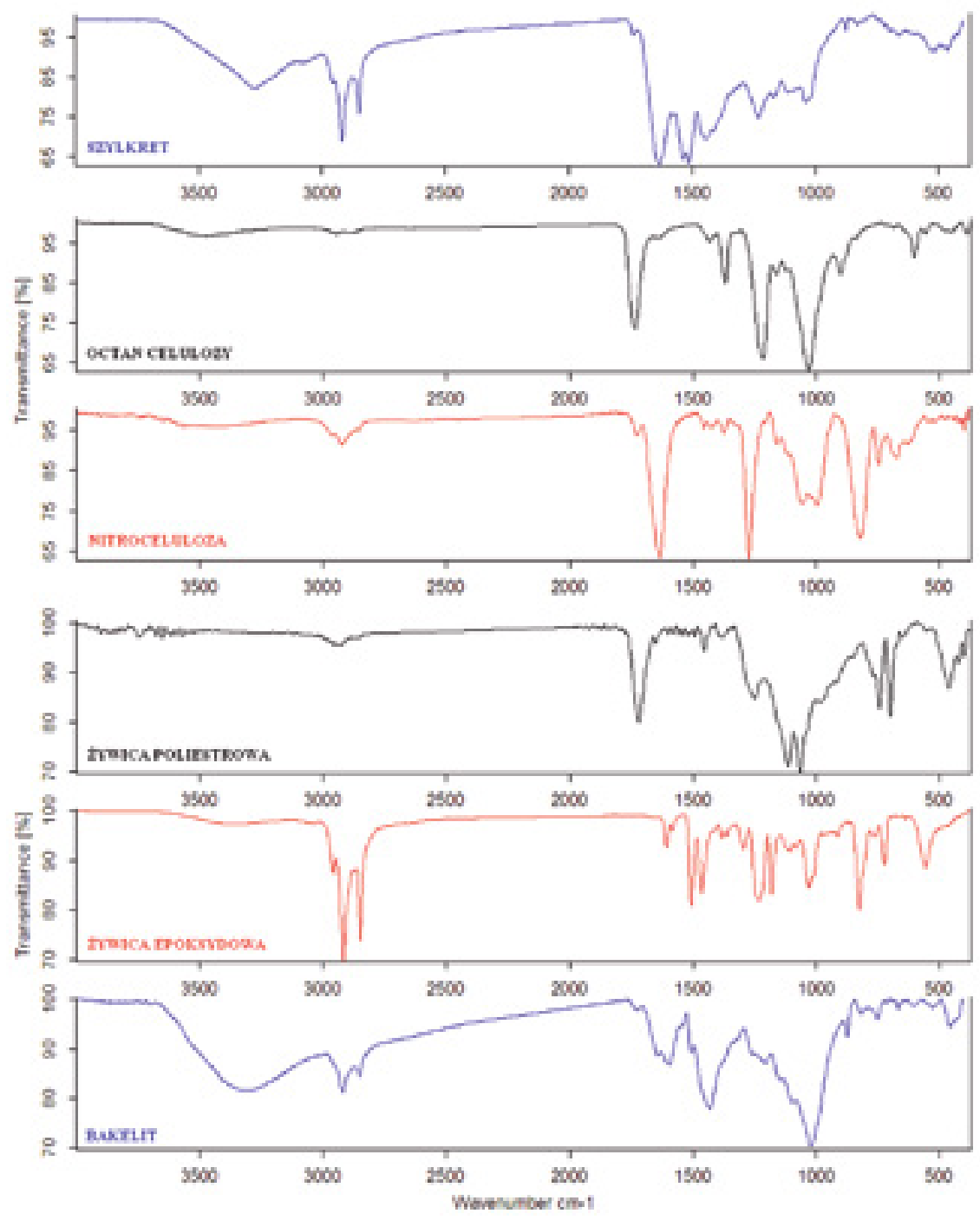

Rys. 4. Widmo w podczerwieni szylkretu oraz tworzyw sztucznych stosowanych do jego imitacji (Zakład Konserwacji Elementów i Detali Architektonicznych, Wydział Sztuk Pięknych, UMK) 